International Review of Research in Open and Distributed Learning Volume 17, Number 6

December - 2016

\title{
Tele-proximity: Tele-community of Inquiry Model. Facial Cues for Social, Cognitive, and Teacher Presence in Distance Education
}

\author{
Dr. Chryssa Themeli ${ }^{1}$ and Anna Bougia ${ }^{2}$ \\ ${ }^{1}$ Bolton University, UK, ${ }^{2} \mathrm{New}$ York College
}

\begin{abstract}
Distance education is expanding in all continents, and the use of video has dominated internet. Synchronous Video Communication (SVC) has not been an option thoroughly investigated and practitioners, who use and design synchronous learning scenarios, are in urgent need of guidance. Distant learners face many barriers, and as a result, they drop out more frequently than on-campus students. Educators seem to be equally affected by the "transactional distance" and the new digital literacies needed for facilitating online learning. This study explores the educators' perspective on how SVC could offer alternative educational forms and possibilities for distance learning. Findings had indicated that the use of visual communication and human to human contact (prosopogonosia: seeing faces) could have a strong impact on learning and teaching, therefore, a theory called Tele-proximity was formulated. Tele-proximity is defined as online embodiment that explains how instructors and students are connected in synchronous networked environment via tele-operations. SVC creates a sense of place or a stage where online identities perform and highlights recent research on audio-visual signals in communication and team work (Pentland, 2012, 2008). The theory can be seen as an extension of the Community of Inquiry Model (Garrison, Anderson \& Archer, 2000) and a theoretical framework according to which learning objectives could be designed. Transactional distance could be minimized and may be implemented to facilitate more synchronous, visual, and humane options in distance education.
\end{abstract}

Keywords: synchronous video communication (SVC), tele-proximity, networked learning, community of inquiry model, honest signals, embodied cognition

\section{Introduction}

Video is everywhere. More and more web content in the years to come will be available in a video format. Even presentations and CVs are turned into video. The YouTube statistics (Statistics YouTube, 2015) have monitored a 40\% increase since March 2014 in the number of people engaging with video either producing 
it or viewing the content. The online magazine Forbes Insights puts emphasis on the fact that executives and business people prefer using the non-text format for various goals (Forbes, 2010). Visual thinking strategies, video storytelling, and Vlogs for reflection are on the rise. According to the National Commission on writing (2006, p.15), "Thinking on the screen" is as important as "thinking on paper" in the 21st century. The implementation of video technology as a reflection tool for students and teachers is not a new concept (Sherin \& Van Es, 2005). Research reported several benefits on teachers' reflective ability regarding interpersonal relationships and classroom management after the implementation of video in their classroom (Bryan \& Recesso, 2006; Calandra, Brantley-Dias, Lee \& Fox, 2009). Generally speaking, synchronous video communication is integral part of all mobile devices, e-learning platforms, and social networks sites.

The importance of audio-visual cues in decision making and communication has been the focus of MIT lab for almost a decade. The so-called "Honest signals"(Pentland, 2012) need to be taken into consideration when distance courses are structured and the research work on social dynamics or social physics shed new light into how could educators build great teams online by using video-conference which research considers the next best form of communication after face-to-face (Pentland, 2012).

Distance education is expanding rapidly in many fields globally and more and more people choose "anytime anywhere" courses (Power \& Morven- Gould, 2011). In the same train of thought, the MIT final report 2016 claims that online learning is as a catalysts for reforms in higher education. Synchronous Video Communication (SVC) has not been an option thoroughly investigated (Hrastinski, Keller, \& Carlsson, 2010) despite the fact that it is widely spread in medicine, businesses, and politics. Hrastinski, Keller, and Carlsson (2010), heightens the need for more research attention to synchronous e-learning because practitioners, who use and design synchronous learning scenarios, are in urgent need of guidance (Hrastinski et al., 2010) and they do not use them as effectively or extensively to facilitate the teaching process (Bower, Kennedy, Dalgano, Lee, Kenney, \& de Barba, 2012; Smyth, Andrews, Bordujenko, \& Caladine, 2011). In the same line of thought, Tomadaki, Quick, \& Scott (2008) indicate that greater integration of videoconferencing with open learning environments and other social media tools needs to be studied to make better sense to learners (Gillies (2008) deems that transferring face-to-face approaches to the videoconferencing suite is inadequate. Furthermore, the literature in the field of video enhanced synchronicity is to a large degree, uncharted and unorganized (Bower et al., 2012).

This paper, taking into account the gaps in the field of synchronous video enhanced communication, formulated a theory called Tele-proximity. The study shed light on the educational experiences of professors who teach online using synchronous video communication and compared it with current research literature.

\section{Methodology}

The research took place in the field of networked learning interdisciplinary courses for undergraduates and postgraduates, from a potentially international perspective, since the interviewees came from four 
continents and ten countries (the UK, the USA, Australia, Canada, France, Greece, Cyprus, South Korea, South Africa, and Spain). On average, the participants had 8.2-year experience in teaching distant courses and used synchronous teaching approaches for 5.6 years. The experience in terms of years, was the basis upon which the theoretical sampling was chosen, because the least experienced faculty, when using educational technology, perceive the obstacles as greater than the most experience ones (Byrne \& McCoy, 2012).

The research ontology is philosophically in the spectrum of relativism and epistemologically speaking, the study is labelled in interpretivist paradigm. The methodology is Informed Grounded Theory (Dunne, 2011; Thornberg, 2012) and data was collected by semi-structured interviews. Community of Inquiry model (Garrison et al., 2000) gave some guidelines as to how to develop themes into interview questions.

Eighteen well experienced instructors had participated. The data was categorized based on the rationale of open, axial, and selective coding. The final stage was to present the core category, teaching approaches, and the contextual factors that influence SVC praxis. At the end, critically reflecting on the memos of the research, the literature form interdisciplinary research such as cognitive psychology and social physics, the criteria of Informed Grounded Theory, and the research outcomes, the researcher built the theory of Teleproximity.

\section{Literature Review on Community of Inquiry Model}

The need to create presence from a distance that is spatial, social, and cognitive is the theory of the Community of Inquiry (CoI). The CoI framework was created to explore, mainly, asynchronous computermediated communication (CMC) in higher education (Xin, 2012). It is aligned with social constructivism and based on John Dewey's (1938) theory of Practical Inquiry. It has been 13 years since Randy Garrison, Terry Anderson, and Walter Archer (2000) first introduced the Community of Inquiry (CoI) model and the framework has "been adopted and adapted by hundreds of scholars working throughout the world" (Garrison, Anderson, \& Archer, 2010a, p.5), and cited in more than 1300 scholarly papers. The journal Internet and Higher Education which released a special issue: The Community of Inquiry Framework: Ten Years Later (Swan \& Ice, 2010), in the first article written by the three original authors who reflect and reevaluate the development of CoI (Garrison et al., 2010a), is followed by seven additional articles that further criticize different aspects of the theoretical model (Xin, 2012). Research, both conceptual and empirical, made an effort to either expand or specify different aspect of the Community of Inquiry. Findings altered (Garrison, 2007; Garrison \& Arbaugh, 2007) perspectives of the model (Arbaugh \& Hwang, 2006; Garrison \& Cleveland-Innes, 2005; Shea, Fredericksen, Pickett, \& Pelz, 2005; Shea, Sau Li, \& Pickett, 2006).

The CoI model not only highlights the role of transactional interactions among learners - but also the role between the trainer and the learners - and how that role can create connections in the online stage. Teacher, social, and cognitive presences are key factors in the components regarding distance education in the theoretical framework of Community of Inquiry (Jézégou, 2012). The model describes behaviors and 
processes in order to cultivate teaching, social, and cognitive presences that facilitate teaching and learning.

The CoI framework focuses on social learning as a process of community building "with an emphasis on the processes of instructional conversations that are likely to lead to epistemic engagement" (Shea \& Bidjerano, 2009, p.545). Epistemic engagement can be defined as dialogue that negotiates meaning and constructs knowledge (Larroeamendy-Jerns \& Leinhardt, 2006). To top it all, Jézégou (2010) claimed that it heuristically provokes research on educational technology.

\section{Critique of the Col Model}

The critique of CoI model has identified some gaps that could be creatively filled. The primary weakness of CoI model relates to the hypothesis that presence promotes learning and enhance performances. Rourke and Kanuka's (2009) review of the empirical research over the last decade deems that this hypothesis has not been verified yet. In response to this argument, Garrison (2011) said that CoI has mistakenly got caught in a higher order philosophical and methodological argument. After all, constructivism epistemology puts emphasis on the process of knowledge construction and supports the multiple views of reality as the nature of knowledge rather than clarifying as objectivism what is right and wrong.

In a review of the CoI literature, Rouke and Kanuka (2009) raise concerns about the lack of focus on deep and meaningful learning, suggesting that many issues examined are peripheral to the CoI framework, such as student satisfaction. They note that most studies report that cognitive presence remains at the lower levels of cognition. In a subsequent response, Akyol, Vaughan, and Garrison (2011) claim that the CoI framework underlines the process of learning and not the outcomes, per se. They explain that the lack of cognitive achievement identified in some studies reflects a weakness in the educational experience, such as a lack of teaching presence, rather than a failure of the CoI framework itself.

In a more recent review of the framework, Jézégou (2010) responds to the critique of Rouke and Kanuk(2009) and she adds that refinement of the indicators used in the three coding schemes is necessary in order to avoid overlap in their use in studies that consider all three presences in parallel. She admits though that Garrison and Anderson (2003) do not make the theoretical model very clear in order to enhance construct validity.

Xin (2012) argues that "CoI underestimates the complex nature of communication which combines instruction, knowledge construction, and social interaction in a single utterance" (para.1). She deems as confusing the relation of cause and effect in the CoI framework and the leadership roles of teaching presence intertwined with the social and cognitive functions. It argues that social presence goes beyond a mere aspect or component of online discussion; it is the backdrop of everything that goes on. "All online utterances are inherently social despite their apparent intention. The relatively unstructured nature of intellectual engagement is contrasted with the four-stage cognitive development assumed by the CoI framework" (Xin, 2012, para. 1). 
Another gap that was ignored in the learning process is the role emotions play. A revised version of CoI includes an emotional presence (Miyazoe \& Anderson, 2015) and the research of Cleveland-Innes and Campbell (2012) made an effort to address this by adding emotional presence as a separates function in the CoI graph.

Other gaps in the Col model served as a powerful guide for the SVC study. The popular Community of Inquiry framework (CoI) is used a lot for text-based asynchronous online discussion (Garrison, Anderson, \& Archer, 2000; Xin, 2012). This model evolved over the years to include verbal interactions, synchronous and asynchronous tools of communication without the body language being perceived (Jézégou, 2012). In a nutshell, the explanatory function of a CoI approach is based on the educational purpose, processes, and context that create a learning community. As it is defined so far, there is no reference to the synchronous video-mediated context and the educational purposes it could serve. Finally, CoI focus is on problem based pedagogy based on the indicators for cognitive presence, while SVC can be associated with diverse educational objectives and teaching approaches.

This review of the CoI framework was written to identify the aspects needing further development and some of them were investigated in the tele-proximity theory explained below.

\section{Findings}

\section{For what educational purposes (learning objectives) do instructors use synchronous teaching approaches?}

The research participants have pointed out that SVC could not only be used to negotiate or construct meaning (as emphasized by the CoI model) but it could be more widely used. They can communicate synchronously to bridge transactional distance as a form of immediacy and intimacy: to resolve conflicts, support, and mentor students. SVC may facilitate learning by explaining difficult subjects, participating in problem-based activities, assigning roles as in role-playing, teaching practical skills and procedures, managing synchronous online dialogue, and giving personalized feedback.

Occasionally, respondents orchestrated content revision and personal or group reflection where participants were focusing on how, why, and what they have learnt. Under certain circumstances, they even archive the video sessions for recycling good praxis. These possibilities for using SVC are potentially significant for addressing the problem of overcoming the high student dropout rates in distance learning courses that are indicated in the research literature (Baxter, 2012; Power \& Morven- Gould, 2011). Informants explained that they could resolve issues, through online discussions with their students, support, and mentor them in a different way than by e-mails or telephone calls, adding a personal touch to the communication for those who needed it. In the cases where complex subject matter is taught, such as in statistics, students may need to ask more questions to reach a learning outcome. For practical skills, such as medical procedures, video is used for learning and reflecting on the process and asking questions along the way. 
Another example is language learning where communication and role playing could give real-life experiences to students talking with native speakers. Finally, it can be articulated that applying synchronously vlogs is an example of a modern view of the Socratic approach that stimulates synchronous reflectivity in order to know better oneself and what or how the student has learnt.

\section{The Theory of Tele-proximity}

The core category (Figure 1.1) of the selective coding process (Informed Grounded Theory) is identified by the researcher based on respondents' perception as Tele-proximity, the need for human to human (embodied) interaction through tele-operations to promote learning objectives, improve communication, and bridge transactional distance in online courses. The term was inspired by the Networked Learning (NL) philosophy (Steeples \& Jones, 2002) that stresses the importance of human-to-human connection in the online context and the transactional distance theory (TDT). Transactional distance theory (TDT) refers to the closeness of the connections between participants in an online NL environment, and the degree to which this enables them or hampers their ability to construct knowledge and facilitate understanding (Moore, 1980).

The study describes real-time, video enhanced, human-to-human connections in distance education which are perceived by most informants as a new genre of social interaction (Themelis, 2013, 2014). Instructors/interviewees in this study underlined the emotional, social, and cognitive need to minimize transactional distance with the use of SVC and students in Baxter's (2012) research felt the same. Informed by Pentland (2012) research, videoconferencing is the next best thing in communication in the business sector. Knowing visually who the educators talk to and with seems to qualitatively change the content of communication, and as such, the communication reinforces the flow of connections.

The emotional needs of students are also evident in the research of Cleveland-Innes and Campbell (2012): "Emotional presence is the outward expression of emotion, affect, and feeling by individuals and among individuals in a community of inquiry, as they relate to and interact with the learning technology, course content, students, and the instructor" (para. 1). However, in the Tele-proximity model, emotions are integral part of social, cognitive, and teacher presence and are not a separate category. The reason for this is because the framework of interpretation is based on the research of Dr. Pentland at the MIT: Social Dynamics Lab (honest signals and great teams) which put great emphasis of the process of mimicry (mirroring behaviors), voice, and audiovisual cues in every aspect of communication and the decisionmaking process. In addition, research demonstrates that "emotion is, indeed, relevant to every dimension of language-from phonology to lexicon, grammar and discourse-emotional expression is finely tuned to language-specific structures" (Saw et al., 2008, p.441). Therefore, presences are complex and defined under different light from the research of Cleveland-Innes and Campbell (2012).

Tele-Teacher Presence (TTP) could be defined in the study as expression of an embodied identity (audiovisual presence) that mirrors or imitates thinking process, behaviors, emotions, and aesthetics for the purpose of realizing personally meaningful learning outcomes and a sense of "place" for online students 
and educators as well. The original definition of teacher presence focuses on instructional management, building understanding, and direct instruction (Garrison et al., 2000). The new element added to the original definition was the projection of aesthetics, mimicry of thinking, behavior, and emotions that could be transmitted easier in synchronous video-enhanced environments and define educator identity, professional salience, and audio-visual presence "on-stage."

On the stage of Tele-proximity, Tele-Cognitive Presence (TCP) is defined as the extent to which learners and educators are able to make their thinking and feelings visible, construct and confirm meaning, learn skills, and play roles through sustained sensory rich reflection (offline embodiment) and discourse (online embodiment) "on-stage." The new understanding of cognitive presence includes educators in the definition because they are integral part of the learning process. Emotions, practical skills or online roles, discourse, and reflection are presented on the "stage" of Tele-proximity. This could be explained in terms of embodied cognition theory (Iacoboni, 2009; Lakoff, 2008). McNerney (2011) explain:

Cognitive science calls this entire philosophical worldview into serious question on empirical grounds... [the mind] arises from the nature of our brains, bodies, and bodily experiences. This is not just the innocuous and obvious claim that we need a body to reason; rather, it is the striking claim that the very structure of reason itself comes from the details of our embodiment. Thus, to understand reason we must understand the details of our visual system, our motor system, and the general mechanism of neural binding (McNerney, 2011, para.2).

Lakoff and Johnson (1999, 2003) and Bergen (2012) assert that people may understand language by simulating in their minds what it would be like to experience the things that language describes. Embodiment seems to be consistent with Pentland's (2008, 2010) work on honest signaling which considers communication as embedded in biology. "If we're spending time together, and I'm happy and bubbly, you'll be more happy and bubbly. There are biological functions that transfer the signals. If I'm happy, it almost literally rubs off on you" (Pentland, 2008, para.4).

Similarly, Iacoboni's (2009) study, Mirroring People: The Science of Empathy and How We Connect With Others, claims that there are "smart cells" in brain that allow people to understand others. From imitation to morality, from political affiliations to consumer choices, mirror neurons are relevant to myriad aspects of social cognition. Amazingly, mirror neurons become also active when individuals are completely still, and they are watching those same actions performed by other people. By watching the actions of others, personal experiences are reflected as a mirror to the brain through a process of simulation. These cells help to understand the mental states of other people, all the gestures made when people speak and when they see (and hear) other people gesturing and speaking. Those gestures seem so intrinsically tied to language.

"Cognition is embodied when it is deeply dependent upon features of the physical body of an agent, that is, when aspects of the agent's body beyond the brain play a significant causal or physically constitutive role in cognitive processing” (Wilson \& Foglia, 2011, para.1). George Lakoff (2012, p.773,) explains the central concepts of embodied cognition in terms of the Neural Theory of Thought and Language (NTTL). Central to NTTL are the following ideas: 
(a) We think with our brains, that is, thought is physical and is carried out by functional neural circuitry.

(b) What makes thought meaningful are the ways those neural circuits are connected to the body and characterize embodied experience.

(c) So-called abstract ideas are embodied in this way as well, as is language.

Experimental results in embodied cognition are seen not only as confirming NTTL but also explained via NTTL, mostly via the neural theory of conceptual metaphor. As Lakoff and Johnson (2003) points out, metaphors are more than mere language and literary devices, they are conceptual in nature and represented physically in the brain. Thus, tele-cognitive presence is a qualitatively different online experience and offline memory.

Tele-Social Presence (TSP) is defined as the ability of participants to create their identity in a sensory rich "stage," communicate purposefully in a trusting environment and develop inter-personal relationships by ways of projecting their individual experiences, ideas, and feelings. The new elements of social presence in comparison with the Community of Inquiry Model (Garrison et al., 2000), is that social interactions are defined in a different context- human-to-human visual presence-. Visual presence could provide much more conscious and unconscious information that affect the quality of communication and affect social trust.

Previous research has found that: "Learners rated items focused on communication needs and being treated as individuals as most important, aligning their stated preferences with the instructors 'perceptions of what actions are most satisfying to online learners" (Dennen, Darabi, \& Smith, 2007, p.65). "When designing an educational experience supported by computer conferencing, consideration should be given to an initial face-to-face meeting where relationships and a comfort level can be established" (Garrison et al., 2000, p. 97).

The contextual factors indicated by respondents are grouped into five main categories. The first group is factors based on the policy of the university to invest in time and capital to improve technologies, training, technical support, and offer incentives for educators and students to make wise use of the capacities of synchronicity. Secondly, time zone differences or the schedules of students who work (often the case for mature students), could provide obstacles to online sessions. Thirdly, technologies (tools, software, and bandwidth) often create more difficulties that could not be easily foreseen. The profiling of actors and the target audience (instructor and student identity, learning styles, pedagogy, personality traits, academic expectations, job satisfaction, digital literacy, language, and cultural background) create the specific climate for learning (contextual aesthetics) that needs to be carefully considered. The fourth group of factors can be divided into two sub-categories: student identity and instructor identity. Finally, the learning objectives needs to be clear from the outset. All these factors may influence performance, perception, and impression. These contextual factors are the elements which shape the "stage" on which synchronous video enhanced learning and teaching are performed. 


\section{Tele-Proximity}

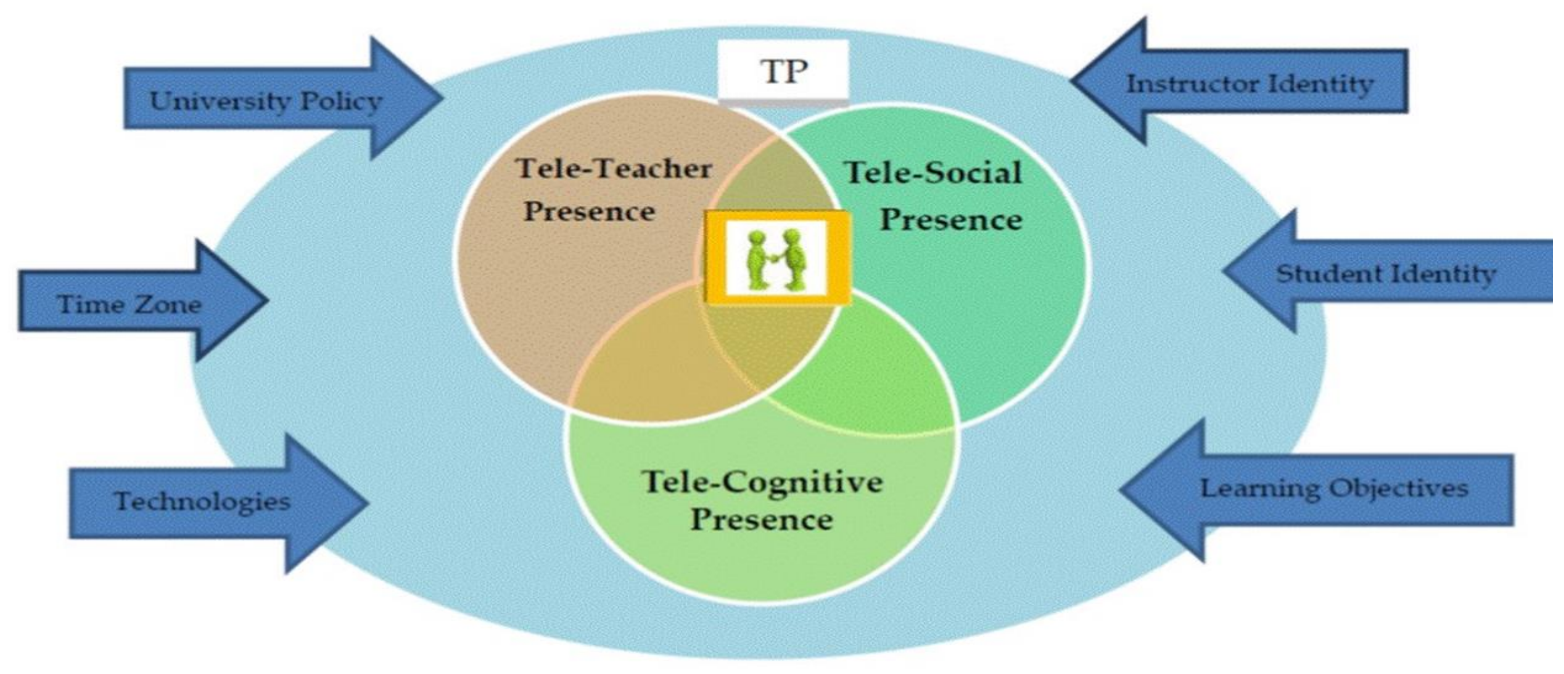

Figure 1.1. Tele-proximity model: The blue section is the stage (SVC context) on which online presences perform while interacting one another in order to build a sense of "place." The arrows represent different affecting factors that could create the ecosystem of tele-proximity stage. The point where the three dimensions intersect is the educational experience of human-to-human connection that tele-operations provide.

In other words, the model is not a simulation of what educators do in face-to-face classes. Rather, it relates to interactional means such as synchronous video. The essential feature of tele-proximity is the sense of place (online campus) and the embodiment of online learning and teaching via tele-operations which provides a different educational experience from both real-time instruction and asynchronous learning because of the audio-visual cues.

Educational technologies promise to improve visual, auditory, spatial, and haptic (touch sensitive) aspects of communication. The sense of embodiment is a significant dimension in the learning process via synchronous, video-mediated communication. Eyes pick up cues to attention, turn taking, aesthetics, and sometimes even deception (Kappas \& Krämer, 2011). Hands and body complement speech at both conscious and unconscious levels. Dialogue is a continuous and intimate coupling of speaker and listener. Space awareness could be transformed into a sense of immersion in the environment. 
The embodied perspective maintains that knowledge during online synchronous meetings is generated by complex and dynamic human communication. Learning can be seen as both online embodiment (making real time judgments) and offline embodiment/offline reflections (recalling of embodied memories). As a concept, Tele-proximity explains how synchronous video enhanced presence (online-embodiment) promotes human-to-human connections and immediacy.

Tele-proximity defines the proximity (i.e., nearness/immediacy) is brought to a group of people via telecommunication systems, computer networks, and so on (Kreijns ,Kirschner, \& Jochems, 2002, p.14). Proximity (Festinger, Schachter, \& Back, 1950) enhances the quality of social relationships. The choice of speech during SVC can vary on personal proximity, including tele-proximity of the addressee to the speaker (Ferriday, Hodgson, \& Jones, 2006). If there is more trust in the addressee, the speaker is likely to adopt a more friendly/less formal speech genre. Form of SVC communication has two parts: one that concerns the sequence of messages, and the addressivity: to whom it is sent. "Presence and proximity in these environments become forms of tele-presence and tele-proximity, that rely more heavily on interactional means to achieve identity formation" (Jones, Ferreday \& Hodgson, 2008, p. 100). In short, the tone of voice, the choice of words, and the way a person talks in front of a camera could influence proximity and affect projection of self within the community. It is what research participants named "a human touch." In the study, Tele-proximity as the ecology of the Tele-CoI is considered a new theory.

The theory explains that SVC has the potential to enhance nearness in distance education by seeing the roles of tele-teacher, tele-cognitive, and tele-social presences form another perspective of embodiment "onstage." Embodiment expands the CoI to better adapt it to include video enabled synchronicity. The collection of data shows that powerful connections can be made through social interactions which are synchronous and video-mediated. The theatrical metaphor of "stage" originated with Goffman (1959) to explain human behavior in social interactions. The findings of Fayard's (2006) research has shown that the "stage" of social interactions where online identities perform is very important in the context of SVC. Moreover, her findings show that people in video-mediated environments adjust and develop habits and routines similar to those in everyday communication in order to build a "stage" for communication. The stage refers to a shared social context, a "place" that participants attend. In short, being in this "place," educators and learners are audio-visually present and perform as actors and audience.

Tele-proximity offers the potential to communicate synchronously and face-to-face via tele-operations which create the circular "stage" for proximity (human-to-human connection) that transforms all presences to embodied entities. To illustrate further, the identity of the instructor, the learning process, the content presentations, and social interactions are influenced by Tele-proximity as audio visual communications via tele-operations offering video enhanced face-to-face contact.

Tele-proximity like an ecosystem creates the theatrical stage up on which presences appear and perform. The new theory claims that Tele-proximity and the Tele-Community of Inquiry model living harmoniously together, have the potential to reduce transactional distance while serving educational purposes for elearning courses because it is what educators (Themelis, 2014) and students (Baxter, 2012) ask for. Teleproximity alters presences because of the audio-visual cues and the human need to be connected as 
embodied entities. The point where the three dimensions intersect is the educational experience of human to human connection that tele-operations provide.

Synchronous video enhanced dialogue seems to affect the identity of instructors and learners because it could facilitate involvement/discussion in online environment. Educators maintained that the value of SVC is dialogue and audiovisual cues. Bower (2011) draws on the work of other researchers and maintains that discursive interaction adjusts the direction of the online session while providing the opportunity for all lifelong learners to engage in knowledge construction. Audio visual communication could give the opportunity for more timely and clear exchange of messages than asynchronous communication. Voice and vision, according to the data collected, give a touch of liveliness to the construction of the online teaching persona. Audiovisual cues influence perception and emotional contagion. Walther's (1992) social information processing theory suggest that educators could build their identity in mediated environments. Sometimes users may not be consciously aware of technological distortions such as the amount of delay may not be noticeable at a "conscious level" (Powers et al., 2011, p.1652). Unconsciously though, technological implications or lack of digital skills could influence negative perception about the teaching identity (Power \& Morven- Gould, 2011). Audio visual cues affect emotional contagion and help build good teams if there is enough communication flow with all member of the group (Christakis \& Fowler, 2009; Pentland, 2008, 2012).

"According to sympathy (the act or capacity of entering into or sharing the feelings or interests of another), humans synchronize facial expressions, vocalizations, and postures unconsciously and rapidly and as a result of melding emotional states" (Christakis \& Fowler, 2009, p.37). Audiovisual information seems to create the contextual aesthetics of SVC, which can affect the instructor's online profile. Instructors engaged with SVC, have the opportunity to develop the ability of "prosopagnosia," a term used for the ability all humans have to read audiovisual (facial signals) cues and respond accordingly. Christakis and Fowler (2009) and Pentland (2008, 2012) based their assumptions on the so-called mirror neurons system, an area of the brain that imitates facial expressions of others and feels like others (empathy).

\section{Implications for Practice}

Njenga, Fourie (2008) and Parchoma (2011) suggest shifting attention from educational technology as it develops to technology's educational roles and the effects it has on the praxis of teaching and learning. Synchronous video interactions bring a "human touch" that is very much needed by students and instructors in distance education, as this study proved, but there is significant evidence that it could effectively be used in many other fields.

Educators and instructional designers may make use of the Tele-proximity model to enrich curricula with more synchronous activities to serve specific learning objectives and build the nest for more democratic dialogue. The flow of interactions within a group could affect efficiency and productivity (Pentland, 2012) while the tools that enhance communications can play a critical role (Themelis, 2014) in the sense of self- 
salience of the instructors and the shared academic expectation between learners and teachers (Baxter, 2012).

Using the power of videos, educators and students may also create professional online identities. If educators and instructional designers use synchronous teaching approaches effectively, the transactional gap between students and instructors may be reduced and the dropout rate may decline based on what both students and experienced educators need.

Policy makers, taking findings into consideration, may use strategies to train, support, and provide organizational incentives to persuade core faculty to dedicate more time to learn how to use technology for networked learning.

\section{Suggestions for Further Research}

This research took place in an interdisciplinary and international context, involving educators who are considered to be early adopters of SVC. Due to the rise in online enrollment over the past decade (Allen \& Seaman, 2010; Baxter, 2011; Power et al., 2011), researchers, educators, and policy makers have to examine methods and tools that may foster community, improve communication, reduce transactional distance, and ultimately enhance lifelong learning engagement.

It would be interesting to narrow down the research to specific educational purposes and to investigate new synchronous technologies or neuroscience of visual learning. Moveable cameras which free the user from having to sit in front of a computer, face and eye movement tracking devices (Yang, Wu, Hsiao, Tsai, \& Hung 2008), hand gesture recognition (Hurtienne et al., 2010), or 3D holographic representations of participants called TeleHumans (Blanche et al., 2010) deserve more research to determine how they can best be implemented .

Further research may develop suitable indicators for tele-teacher, tele-cognitive, and tele-social presence for the Tele-Community of Inquiry (CoI) model that better utilizes the affordances of SVC. Audio visual presence seems to be affected by what is being said, seen, heard, and done on SV stage in multiple ways. Therefore, more research is required to better explain the factors affecting the digitally embodied learning and teaching. Therefore, studies could investigate more the role of media psychology and embodied cognition through the lens of technology. The e-learners' background is rich in cultural and linguistic diversity and gender. These issues were not specifically examined in this research, yet existing studies have highlighted the challenges associated with gender (Yukselturk \& Bulut, 2009) and cultural differences (Boondao, Hurst, \& Sheard, 2008) in networked learning. These issues also would merit investigation and may shed light on different aspects of SVC.

\section{Conclusion}


Despite the fact that technology can be very chaotic when it does not work properly, it could offer creative and cost effective alternatives when the people involved dedicate the amount of time and effort needed. The portrait of oneself, content, and social interactions on the screen are powerful images that could have an impact on the social, cognitive, or teacher presence which cannot be ignored. It is of prime importance to use effectively all the tools available for synchronous video communication in order to facilitate life-long learning and enhance experiences in distance education.

Note. More detailed information about the research process and the research participants'perspective can be found here: Themelis, C. (2014). Synchronous video communication for distance education: The educators' perspective. Open Praxis, 6(3), 235-245. Retrieved from http://www.openpraxis.org/index.php/OpenPraxis/article/viewFile/150/123

\section{References}

Akyol, Z., \& Vaughan, N., \& Garrison, D.R. (2011). The impact of course duration on the development of a Community of Inquiry. Interactive Learning Environments, 19(3), 231- 246.

Allen, I. E., \& Seaman, J. (2010). Class differences: Online education in the United States [online document]. Retrieved from http:// sloanconsortium .org/ sites/default/files/class differences 31.pdf

Arbaugh, J. B., \& Hwang, A. (2006). Does "teaching presence" exist in online MBA courses? The Internet and Higher Education, 9(1), 9-21.

Calandra, B., Brantley-Dias, L., Lee, J.K., \& Fox, D.L. (2009). Using video editing to cultivate novice teachers' practice. Journal of Research on Technology in Education, 42(1), 73-94. Retrieved from http://dx.doi.org/10.1080/15391523.2009.10782542

Baxter, J.1 (2011). Public sector professional identities: A review of the literature. The Open University, UK. Retrieved from http://oro.open.ac.uk/29793/47/Public service professional identities a review of the liter ature 2012.pdf

Baxter, J. (2012). Who am I and what keeps me going? Profiling the distance learning student in higher education. The International Review of Research in Open and Distance Learning, 13(4), 107129. doi:http://dx.doi.org/10.19173/irrodl.v13i4.1283

Blanche, P. A., Bablumian, A. A., Voorakaranam, R. R., Christenson, C. C., Lin, W. W., Gu, T. T., \& Peyghambarian, N. N. (2010). Holographic three-dimensional telepresence using large-area photorefractive polymer. Nature, 468(7320), 80-83. doi:10.1038. 
Bergen, B. K. (2012). Louder than words: The new science of how the mind makes meaning. New York, NY: Basic Books.

Boondao, R., Hurst, J., \& Sheard, J.I. (2009).Understanding cultural influences: Principles for personalized e-learning systems. International Journal of Behavioral, Cognitive, Educational and Psychological Sciences, 1(1), 66-70.

Bower, M., Kennedy, G., Dalgano, B., Lee, M.J.W., Kenney, J., \& de Barba, P. (2012, November 25-28). Use of media-rich real-time collaboration tools for learning and teaching in Australia and New Zealand universities. . In M. Brown, M. Hartnett \& T. Stewart (Eds.), Future challenges, sustainable futures. In Proceedings ascilite Wellington 2012. (pp.133-144). Retrieved from http://www.ascilite.org.au/conferences/wellington 12/2012/images/custom/bower\%2c matt use of media.pdf

Bower, M. (2011). Synchronous collaboration competencies in web conferencing environments - their impact on the learning process. Distance Education, 32(1), 63-83.

Bryan, L.A., \& Recesso, A. (2006). Promoting reflection among science student teachers using a webbased video analysis tool. Journal of Computing in Teacher Education, 23(1), 31-39.

Byrne, M. M., \& McCoy, T. S. (2012). Faculty-perceived barriers of online education. Journal of Online Learning and Teaching, 8(1).

Christakis N. A., \& Fowler J.H. (2009). Connected: The surprising power of our social networks and how they shape our lives. New York, NY: Little, Brown and Company.

Cleveland-Innes, M., \& Campbell, P. (2012). Emotional presence, learning, and the online learning environment. The International Review of Research in Open and Distributed Learning, 13(4), 269-292. Retrieved from http://www.irrodl.org/index.php/irrodl/article/view/1234/2333

Dennen, V. P., Darabi, A., \& Smith, L. J. (2007). Instructor-learner interaction in online courses: The relative perceived importance of particular instructor actions on performance and satisfaction. Distance Education, 28(1), 65-79 doi:10.1080/01587910701305319.

Dewey, J. (1938). Experience and education. Toronto, Canada: Collier-MacMillan Canada.

Dunne, C. (2011). The place of the literature review in grounded theory research. International Journal of Social Research Methodology, 14(2), 111-124.

Fayard, A. (2006). Interacting on a video-mediated stage. Information Technology \& People, 19(2), 152169.

Ferriday D., Hodgson V., \& Jones C. (2006). Dialogue, language and identity: critical issues for networked management learning. Studies in Continuing Education, 28(3), 223-239. 
Festinger, L., Schachter S. S., \& Back, K. W. (1950). Social pressures in informal groups. Stanford, CA: Stanford University Press.

Forbes. (2010, October 15). Executives embrace non-text world [online document]. Retrieved from http://images.forbes.com/forbesinsights/StudyPDFs/Video in the CSuite.pdf

Garrison, D. R., Anderson, T. \& Archer, W, (2000). Critical inquiry in a text-based environment: Computer conferencing in higher education. The Internet and Higher Education, 2(2-3), 87- 105.

Garrison, D. R., \& Cleveland-Innes, M. (2005). Facilitating cognitive presence in online learning: Interaction is not enough. American Journal of Distance Education, 19(3), 133-148.

Garrison, D. R., \& Arbaugh, J. B. (2007). Researching the community of inquiry framework: Review, issues, and future directions. The Internet and Higher Education, 1O(3), 157-172.

Garrison, D. R. (2007). Online Community of Inquiry review: Social, cognitive, and teaching presence issues. Journal of Asynchronous Learning Networks, 11(1), 61-72.

Garrison, D. R., Anderson, T., \& Archer, W. (2010a). The first decade of the community of inquiry framework: A retrospective. The Internet and Higher Education, 13(2), 5-9.

Garrison, D. R. (2011). E-Learning in the 21st century: A framework for research and practice (2nd ed.). London, UK: Routledge/Taylor and Francis.

Gillies, D. (2008). Student perspectives on videoconferencing in teacher education at a distance. Distance Education, 29(1), 107- 118.

Goffman, E. (1959). Presentation of self in everyday life. New York, NY: Doubleday.

Goffman, E. (1974). Frame analysis. Boston, MA: Northeastern University Press.

Hrastinski, S., Keller, C., \& Carlsson, S. A. (2010). Design exemplars for synchronous e-learning: A design theory approach. Computer \& Education, 55(2), 652-662.

Hurtienne, J., Stößel, C., Sturm, C., Maus, A., Rötting, M., Langdon, P., \& Clarkson, J. (2010). Physical gestures for abstract concepts: Inclusive design with primary metaphors. Interacting with Computers, 22, 475-484.

Iacoboni, M. (2009). Imitation, empathy and mirror neurons. Annual Review of Psychology, 3o(1), 653770.

Jézégou, A. (2010).Community of inquiry in e-learning: A critical analysis of Garrison and Anderson model. Journal of Distance Education, 24(3), 1-18. Retrieved from http://www.jofde.ca/index.php/jde/article/view/707/11415 
Jézégou, A. (2012). Presence in e-learning: theoretical model and perspectives for research. Journal of Distance Education / Revue de l'Education à Distance, 26(2). Retrieved from http://www.ijede.ca/index.php/jde/article/view/809

Jones, C. R., Ferreday, D. D., \& Hodgson, V. V. (2008). Networked learning a relational approach: Weak and strong ties. Journal of Computer Assisted Learning, 24(2), 90-102. doi:10.1111/j.13652729.2007.00271.x

Kappas, A., \& Krämer, N. (2011). Face-to-face communication over the internet. Cambridge, UK: Cambridge University Press Textbooks.

Kreijns, K., Kirschner, P., \& Jochems, W. (2002). The sociability of computer -supported collaborative learning environments. Educational Technology \& Society, 5(1), 8 -22.

Lakoff, G. (2012). Explaining embodied cognition results. Topics in Cognitive Science, 4(4), 773-785.

Lakoff, G., \& Johnson, M. (1999). Philosophy in the flesh: The embodied mind and its challenge to western thought. New York, NY: Basic Books.

Lakoff, G., \& Johnson, M. (2003). Metaphors we live by. Chicago, IL: University of Chicago Press.

Lakoff, G. (2008). The political mind. New York, NY: Viking.

Lakoff, G., \& Nunez, R. E. (2000). Where mathematics comes from: How the embodied mind brings mathematics into being. New York, NY: Basic Books.

Larreamendy-Joerns, J., \& Leinhardt, G. (2006). Going the distance with online education. Review of Educational Research, 76(4), 567-605.

McNerney, S. (2011, November 11). A brief guide to embodied cognition: Why you are not your brain. Scientific American. Retrieved from http://blogs.scientificamerican.com/guestblog/2011/11/04/a-brief-guide-to-embodied-cognition-why-you-are-not-your-brain/

Miyazoe, T., \& Anderson, T. (2015). Interaction equivalency in an OER, MOOC and informal learning era. Best of Eden 2013 Issue - EURODL 2013 Issue. Retrieved

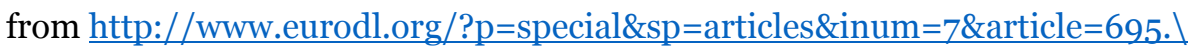

Moore, M. G. (1980). Independent study. In R. D. Boyd, Apps, J. W., \& Associates (Eds.), Redefining the discipline of adult education (Vol. 5, pp. 16-31). San Francisco, CA: Jossey-Bass.

National Commission on Writing in America's Schools and Colleges. (2006). Writing and school reform. Washington, DC; College Entrance Examination Board. Retrieved from http://www.collegeboard.com/prod downloads/writingcom/writing-school-reform-natl-commwriting.pdf 
Njenga, J. K., \& Fourie, L. C. H. (2008). The myths about e-learning in higher education. British Journal of Educational Technology, 41(2), 199-212.8doi:10.1111/j.1467-8535.2008.00910.x

Parchoma, G. (2011). Toward diversity in researching teaching and technology philosophies-in- practice in e-learning communities. In B. Daniel (Ed.), Handbook of research on methods and techniques for studying virtual communities: Paradigms and phenomena (Vol. 1, pp. 61- 86). Hershey, PA: IGI Global.

Pentland, A. (2008). Honest signals: How they shape our world. Cambridge, MA: MIT Press.

Pentland, A. (2010, January 1). Defend your research: We can measure the power of charisma - Harvard Business Review. Harvard Business Review Case Studies, Articles, Books, Pamphlets - Harvard Business Review, January-February 2010 issue. Retrieved from http://hbr.org/2010/o1/defendyour-research-we-can-measure-the-power-of-charisma/ar/1

Pentland, A. (2012, April). The science of building great teams. Harvard Business Review. Retrieved from https://hbr.org/2012/04/the-new-science-of-building-great-teams

Power, T., \& Morven-Gould, A. (2011). Head of gold, feet of clay: The online learning paradox. International Review of Research in Open and Distance Learning, 12(2), 19-39.

Powers, S. R., Rauh, C., Henning, R. A., Buck, R. W., \& West, T.V. (2011). The effect of video feedback delay on frustration and emotion communication accuracy. Computers in Human Behavior, $27(5), 1651-1657$.

Rourke, L., \& Kanuka, H. (2009). Learning in communities of inquiry: A review of the literature. Journal of Distance Education, 23(1), 19-48. Retrieved from http://www. jofde.ca/index.php/ jde/article/view/474/816

Saw, K. G., Majid, O., Ghani, N. A., Atan, H., Idrus, R. M., \& Rahman, Z. A. (2008). The videoconferencing learning environment: Technology, interaction and learning intersect. British Journal of Educational Technology, 39(3), 475-485.

Shea, P., Fredericksen, E.,Pickett, A., \& Pelz, W. (2005).Increasing access to higher education: A study of the diffusion of online teaching among 913 college faculty. International Review of Research in Open and Distance Learning, 6(2). Retrieved from http://www.irrodl.org/index.php/irrodl/article/view/238/493

Shea, P., Sau Li, C., \& Pickett, A. (2006). A study of teaching presence and student sense of learning community in fully online and web-enhanced college courses. The Internet and Higher Education, 9(3), 175-190. 
Shea, P., \& Bidjerano, T. (2009). Community of inquiry as a theoretical framework to foster "epistemic engagement" and "cognitive presence" in online education. Computers \& Education, 52(3), 543553 .

Sherin, M.G., \& Van Es, E.A. (2005). Using video to support teachers' ability to notice classroom interactions. Journal of Technology and Teacher Education, 13(3), 475-491.

Smyth, R., Andrews, T., Bordujenko, J., \& Caladine, R. (2011). Leading rich media implementation collaboratively: Mobilizing international, national and business expertise [Final project report]. Sydney, Australia: ALTC. Retrieved from http://www.olt.gov.au/system/files/resources/LE7377\%20UNE\%20Smyth\%20Final\%20report\%202011.pdf

Statistics YouTube. (2015, October 13). Retrieved from https://www.youtube.com/yt/press/enGB/statistics.html

Steeples, C., \& Jones, C. (Eds.). (2002). Networked learning: Perspectives and issues. London, UK: Springer.

Swan, K., \& Ice, P. (2010). The Community of Inquiry framework ten years later: introduction to the special issue. Internet and Higher Education, 13(1-2), 1-4.

Themelis,C.(2014). Synchronous video communication for distance education: The educators' perspective. Open Praxis, 6(3), 2014, pp. 235-245 (ISSN 2304-070X). Retrieved from http://www.openpraxis.org/index.php/OpenPraxis/article/vieFile/150/123

Themelis, C. (2013). Teleproximity: The experienced educators' perspective of human to human communication in distance education (Ph.D. thesis). Lancaster University: UK.

Tomadaki, E., Quick, K., \& Scott, P.53 (2008). Videoconferencing in open learning. Journal of Interactive Media in Education, 2008(1). DOI: http://doi.org/10.5334/2008-8

Thornberg, R. (2012). Informed grounded theory. Scandinavian Journal of Educational Research, 56(3), 243-259.

Walther, J. B. (1992). Interpersonal effects in computer-mediated interaction: A relational perspective. Communication Research, 19(1), 52-90.

Wilson, R. \& Foglia, L. (2016), Embodied Cognition In Edward N. Zalta (ed.), The Stanford Encyclopedia of Philosophy. Retrieved from http://plato.stanford.edu/archives/win2016/entries/embodiedcognition

Xin, C. (2012). A critique of the community of inquiry framework. The Journal of Distance Education, 26(1). Retrieved from http://www.jofde.ca/index.php/jde/article/view/755/1333 
Yang, J., Wu, C., Hsiao, C., Tsai, R., \& Hung, Y. (2008, May 28-30). Evaluation of an eye tracking technology for $3 \mathrm{~d}$ display applications. In Institute of Electrical and Electronics Engineers (IEEE) (Eds.), 3DTV conference: The true vision - Capture, transmission and display of 3 d video. Proceedings of the 3DTV Conference (pp. 345-348). Istanbul, Turkey. doi:10.1109/3DTV.2008.4547879

Yukselturk, E., \& Bulut, S. (2009). Gender differences in self-regulated online learning environment. Educational Technology \& Society, 12(3), 12-22.

\section{Athabasca} University

$$
\text { (9) } 0
$$

